\title{
MODEL DESIGN OF SOLAR-DIESEL HYBRID POWER SYSTEM WITH HOMER PRO
}

\author{
Matius Sau ${ }^{1}$, Hestikah Eirene Patoding ${ }^{2}$ \\ ${ }^{I}$ Electrical Engineering Department, Paulus Christian University of Indonesia-Makassar \\ ${ }^{2}$ Electrical Engineering Department, Paulus Christian University of Indonesia - Makassar
}

\begin{abstract}
This research aims to make the development of model Solar-Diesel Hybrid Power system so that the supply of electric energy to the community can be fulfilled continuously. The result of research shows that the development of electric power capacity generated with simulation by hybrid system is $169 \mathrm{~W}$. Previous research [6], the hybrid generator prototype design generates $37.15 \mathrm{~W}$ of power, can turn on $55 \mathrm{~W}$ lamp for $\pm 5,404$ hours by charging accumulator for 8 hours from $08.00-16.00$. The power of $169 \mathrm{~W}$ is expected to turn on the light in the community continuously
\end{abstract}

Keywords-Hybrid System; Solar Cell; Diesel/Genset

\section{INTRODUCTION}

Economic growth is increasing along with the needs of society, such as the use of equipment that uses the dominant electric power. This condition has an impact on the provision of electrical energy that is growing but the source of electrical energy especially that uses fossil energy is thinning, so that needed alternative energy sources such as Solar Power, Wind Power, Geothermal power and so forth.

Indonesia territory consisting of islands, there are still many areas that are not reached by PLN Electricity so that the area using Genset or diesel power plant. This is constrained on the cost of fuel is quite expensive and the cost of distribution is high. Increased economic growth of rural communities requires many things one of them is the availability of electric energy. To achieve this, this paper develops the results of previous research on the design of a hybrid solar power plant system with a diesel power plant as an energyefficient alternative [6] by developing a model and creating a prototype of a Solar Diesel power system with Diesel / Genset in an effort to anticipate the electricity crisis in the countryside and also as an energy-efficient solution with the utilization of solar energy.

\section{LITERATURE REVIEW}

\subsection{Photovoltaic Solar Power System}

Photovoltaic solar power systems commonly used for lighting are individual systems or more often known as solar home systems (SHS).

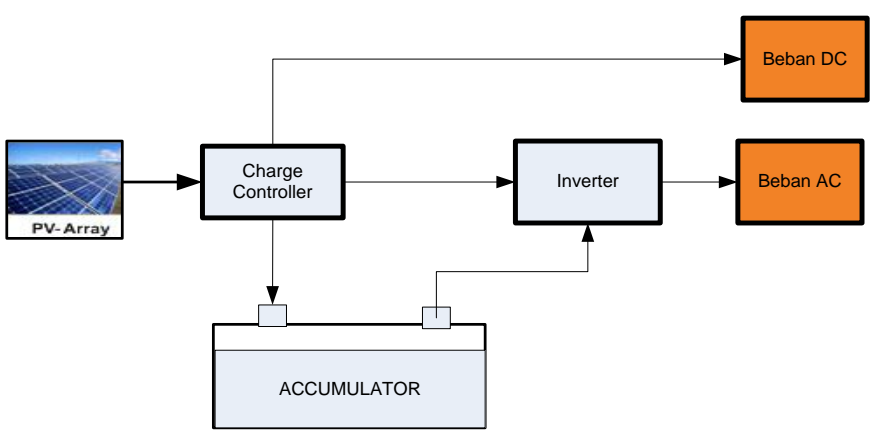

Fig 1: Block diagram of solar module system for PLTS

From Figure 1 it is explained that the energy from sunlight converted to electrical energy by the solar module (Photovoltaics) will be supplied to the controller charger to adjust the charging of electrical energy in the battery. From this charger controller can also be directly used for DC load or directly into the inverter to be converted into AC current voltage. Furthermore, the electrical energy generated by the battery will be converted by the inverter from the direct current voltage (DC) to an alternating current voltage (AC) so that it can be utilized in the current load back and forth.

The most dominant meteorological conditions in designing solar power systems are the amount of daily radiation (Wh / $\mathrm{m} 2$ day), as well as ambient temperatures, while the humidity and wind velocity do not have much effect. [4]

\subsubsection{Component of Solar Power Generation (PLTS)}

\section{Solar Module / PV}

The solar module is a combination of several solar cells connected in series and parallel. One solar cell produces a voltage of 0.45 Volts [12]. 
Determination of the number of solar modules can be calculated using the following equation [14].

$$
n=\frac{P}{P_{n}}
$$

where:

$P=$ Power planned $(\mathrm{kWp})$

$P n=$ The power capacity of each solar module $(\mathrm{Wp})$

\section{Bi Directional Inverter}

$\mathrm{Bi} \mathrm{Bi}-\mathrm{Directional}$ Inverter or often called Inverter serves to convert the voltage current (DC) into an alternating current voltage (AC).

The capacity of the Inverter depends on the capacity of the solar module to be used.

\section{Solar Charge Controller /MPPT}

Solar charge controller / MPPT is a set of electronics components that work for:

1. Manage energy transfer from solar module (PV) to Accumulator / Battery and to load efficiently and maximally

2. Protect the battery from overcharge by disconnecting the battery charging process at the upper limit voltage

3. Protecting overdischarge by deciding the battery discharge process at lower limit voltage

4. Extend battery life

\section{Accumulator / Battery}

Accumulator is an electric storage medium. Broadly speaking the accumulator is differentiated by application and construction.

Based on the application then the accumulator is divided into two (2) ie:

1. Engine starter (otomotif). $\searrow$

Automotive accumulators are generally made with thin lead plates but many so that the surface area is larger. Thus, this Accumulator can supply a large electric current at the beginning to start the engine

2. Deep cycle. Deep cycle accumulator is usually used for photovoltaic systems (solar cell) and back up power, where Accumulator capable of discharging until the electrical charge is low.

The durability of the accumulator relates to the amount of discharging in both types of accumulator shown in Table 1.

Table 1: Filling cycle on Automotive Accumulator type and deep cycle

\begin{tabular}{|c|c|c|}
\hline Depth of Discharge & Starter Battery & Deep-cycle Battery \\
\hline $100 \%$ & $12-15$ cycles & $150-200$ cycles \\
$50 \%$ & $100-120$ cycles & $400-500$ cycles \\
$30 \%$ & $130-150$ cycles & 1,000 and more cycles \\
\hline
\end{tabular}

The accumulator construction is divided into wet type (conventional, flooded lead acid), sealed lead acid (SLA), valve regulated lead acid (VRLA), gel, and AGM (absorbed glass mat), all of which are lead acid-based accumulators ). Table 2 shows the voltage required for the absorption charging process (with maximum current) and float charging (to prevent self discharge) on the Accumulator types.

Table 2: Voltage charging for different types of Accumulator

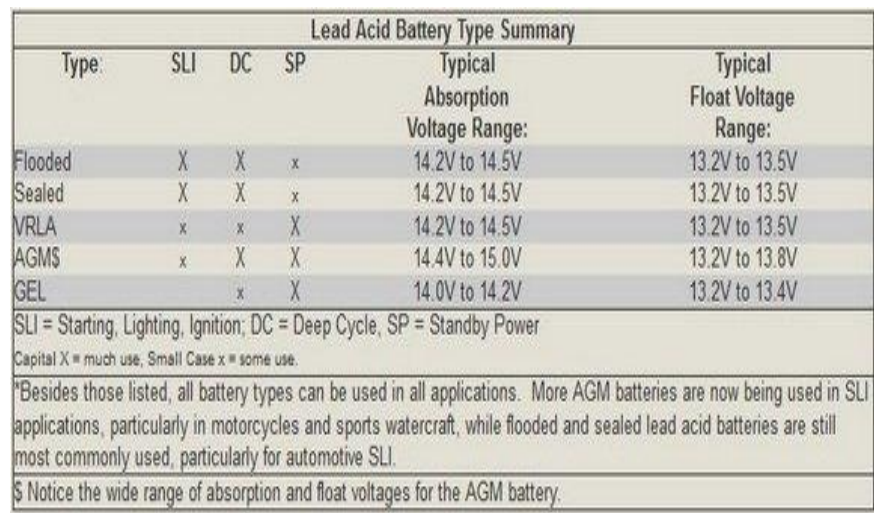

For the sustainability of a system in order to operate properly and in accordance with the needs of the load, it is necessary to consider the situation of sunless weather (autonomi days) which is generally calculated for 5 days.

Battery capacity is calculated by:

$$
C_{b}=\frac{E_{b} \times d}{V \times K_{b}}
$$

where :

$\mathrm{Eb}=$ Energy required load in a day ( $\mathrm{kW}$ - hour)

$\mathrm{V}=$ Battery working voltage $=12$ Volt or 24 Volt

$\mathrm{d}=$ Number of days without radiation year $=5$ days $/$ year

$\mathrm{Kb}=$ Efficiency charging and discharging battery $(\mathrm{DOD}=$ $0.8)$

The required photovoltaic power capacity, depending on the load energy required and the daily solar radiation available on site. The energy to be emitted by photovoltaic modules [15]

$$
E_{\text {out }}=P_{\text {rate }} x H \quad \ldots \ldots \ldots \ldots \ldots \ldots . . . .3
$$

Where:

$\mathrm{E}_{\text {out }}=$ Average daily spent energy (Joule)

$\mathrm{P}_{\text {rate }}=$ average power (Watt)

$\mathrm{H}=$ Average daily radiation

To meet the energy required by the load, the average daily energy output of the circuit should be added to the energy lost in the system by $25 \%$ of the average daily output energy.

Limitations of solar radiation that does not always shine brightly every day can be overcome by using the battery. So that the electrical energy generated by solar cells can be stored in the batteries and used for the needs at night. 
From the results of research conducted to get data that solar cells generate the most powerful electric current for supply at 12 to 13 noon with an optimum slope angle of $15^{\circ}$. [16]

\subsection{Diesel Power Generation / Genset}

Diesel Power Generation in this research is stated as a Genset (generator set) that work using BBM. Genset is a device that produces electrical power, obtained from the conversion of mechanical energy into electrical energy.

Genset consists of two main devices, namely engine and generator (G1) and supported by starter motor (M1), battery and other controls as shown in Figure 2 [1]

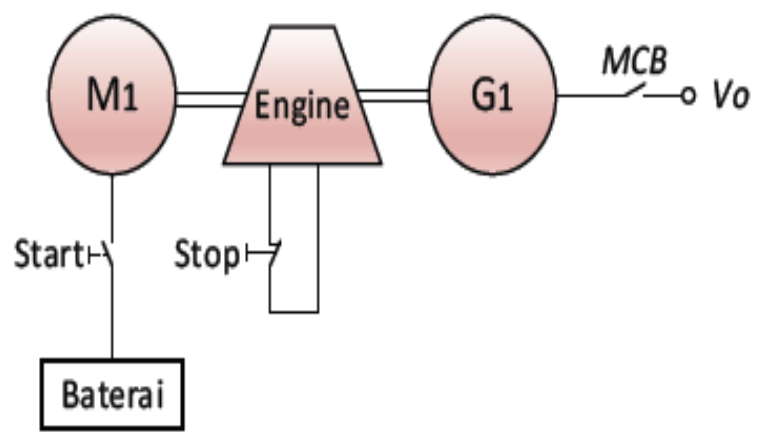

Gambar 2. Single line Diesel/Genset

\subsection{Hybrid PLTS - Genset (PLTD)}

The term Hybrid is defined by the use of 2 or more power plants with different energy sources, commonly used for captive generators, to obtain synergies that provide economic and technical advantages, which means the reliability of the supply system.

The main purpose of the hybrid system is basically to try to combine two or more energy sources (generating systems) so that they can cover each other's weaknesses and can be achieved supply reliability and economical efficiency at certain load (Load profile) type.

Type load (Load profile) is an important keyword in hybrid system. For each different load profile, hybrid system with certain composition will be required, in order to achieve optimum system. Therefore, system design and system sizing plays an important role to achieve the targets made hybrid system

Modeling of hybrid systems can be expressed in two central air conditioned relationships shown in FIG. 3 and centralized AC and DC as shown in figure 4.

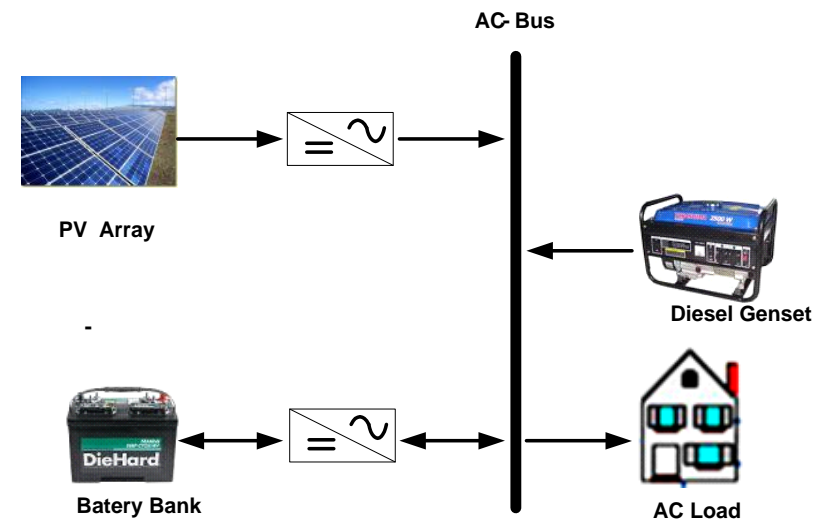

Fig 3: Centralized AC coupled hybrid power system (Centralized AC-coupled Hybrid Power Systems)

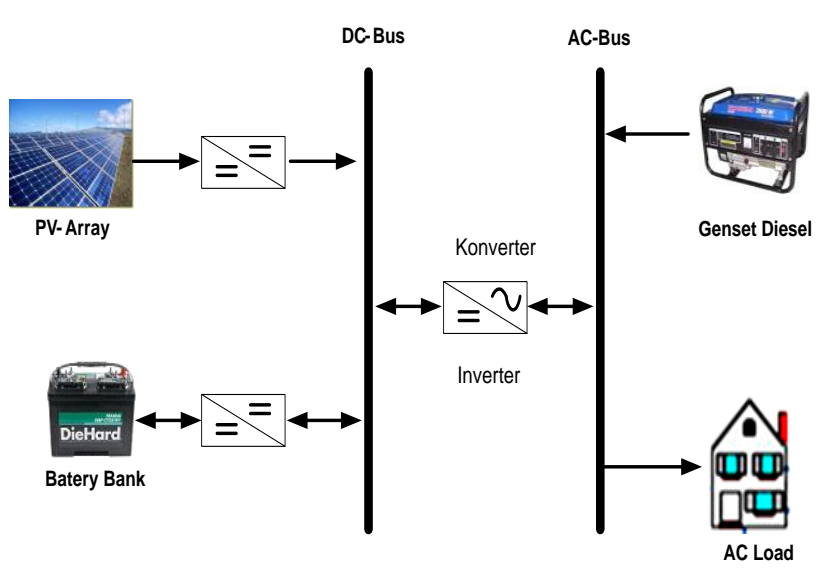

Fig 4: Centralized AC and DC-coupled Hybrid Power Systems hybrid power plant

\section{METHODOLOGY}

In designing the development of the generator model requires the following stages:

A. Total load data $(P)$ and time $(t)$ to be served

B. Calculate the capacity of each component.

\section{Planning for Genset / Diesel}

The electrical power generated by Genset / Diesel can be calculated by:

$$
P_{a c}=V x I x \operatorname{Cos} \emptyset \ldots \ldots \ldots \ldots 4
$$

where:

$\mathrm{V}=$ Voltage AC (volt)

$\mathrm{I}=$ current (Ampere)

$\operatorname{Cos} \emptyset=$ power factor

\section{Planning for Solar Cell}

\section{a. Energy needed is:}

$$
E_{a c}=P_{a c} x t
$$

where:

$\mathrm{Eac}=$ total energy required in $\mathrm{Ah}$ 
Pac $=$ total load served in Watt

$\mathrm{t}=$ total time required to serve the load in hours

\section{b. Battery Capacity}

The Ampere-Hour (Ah) Battery Capacity can be calculated based on the total load served and the operating load time is:

$$
P_{a c}=V_{R M S} x I_{R M S} x P F
$$

$E_{a c}=P_{a c} x t$

$$
E_{a c}=V_{R M S} x I_{R M S} x P F x t
$$

where:

$\mathrm{P}_{\mathrm{ac}}=$ Total consumer power (Watt)

$\mathrm{E}_{\mathrm{ac}}=$ Total Energy Consumer $(\mathrm{Wh})$

$\mathrm{V}_{\mathrm{RMS}}=$ System voltage $(12 \mathrm{~V}$ DC)

$\mathrm{I}_{\mathrm{RMS}}=$ Supplied electrical current $(\mathrm{A})$

$\mathrm{PF}=$ Energy factor conversion of Battery (Power factor $=0.9$ )

$\mathrm{t}=$ Time (hours)

So that

$$
I_{R M S} x t=\frac{E_{a c}}{V_{R M S} \times P F} \quad \ldots \ldots \ldots \ldots . . . .8
$$

where

$I_{R M S} x t=$ kapasitas battery dalam Ah

Inverter efficiency value of $90 \%$, then the remaining $10 \%$ wasted into heat then redefined battery capacity value of $10 \%$ of the value of Ampere hour (Ah) before.

Thus the amount of Battery needed is

Where:

$$
n_{b}=\frac{I_{R M S} x t}{E_{b}} \quad \ldots \ldots \ldots \ldots . \ldots
$$

$\mathrm{n}_{\mathrm{b}}=$ number of batteries

$\mathrm{E}_{\mathrm{b}}=$ capacity of battery $(\mathrm{Ah})$

\section{c. Solar Panel}

In calculating the capacity of solar panels required total consumer power added with the need to charge the battery, then the first known is the amount of current used to charge the battery for 10 hours is

$$
I_{c h}=\frac{I_{R M S} \times t_{d}}{t_{s}} \quad \ldots \ldots \ldots \ldots 10
$$

where:

$\mathrm{I}_{\mathrm{ch}}=$ Battery charge current $(\mathrm{A})$

$\mathrm{I}_{\text {RMS }} \times \mathrm{t}_{\mathrm{d}}=$ Battery Capacity with DOD (Ah)

$\mathrm{t}_{\mathrm{s}}=$ long sunlight (hour)

For solar panels capable of producing Output of $50 \mathrm{Wh}$, the number of solar panels needed is:

$$
n_{p}=\frac{E_{a c}}{E_{p}}
$$

where

$\mathrm{n}_{\mathrm{p}}=$ numbers of panel

$\mathrm{E}_{\mathrm{ac}}=$ total energy and consumer energy (load)

$\mathrm{E}_{\mathrm{p}}=$ Panel capacity $(\mathrm{Wh})$

\section{d. Charge Controller}

The amount of charge controller required depends on the maximum load allowed on the device. To charge Solar Charge Controller MPPT30 12/24 volt (auto) means that the maximum load that can be served is 30 Ampere, then the amount of charge controller used to charge Battery is

$$
n_{c g}=\frac{A h_{B}}{I_{\max -c g} \times t_{s}} \ldots \ldots \ldots \ldots 12
$$

where

$\mathrm{N}_{\mathrm{cg}}=$ numbers of charge controller

$\mathrm{Ah}_{\mathrm{b}}=$ Battery capacity (Ampere hours)

$\mathrm{I}_{\text {max } \_\mathrm{cg}}=$ maximum current of charge controller (Ampere)

$\mathrm{t}_{\mathrm{s}}=$ time of exposure (hours)

\section{e. Power Inverter}

Power inverters are calculated based on the maximum load allowed on the device. Suppose Power Inverter 500 W VMI-P500, has a maximum load of $500 \mathrm{~W}$. Thus for electrical energy required in 1 hour for $500 \mathrm{~W}$ power is $500 \mathrm{Wh}$ then the number of inverters required is:

$$
n_{i}=\frac{E_{a c}}{E_{i}}
$$

Where:

$\mathrm{n}_{\mathrm{i}}=$ numbers of inverter

$\mathrm{E}_{\mathrm{ac}}=$ Total energy (Watt hours)

$\mathrm{E}_{\mathrm{i}}=$ Capacity of inverter (Watt hour)

\subsection{Design Simulation Model with Homer Pro}

\section{V3.9.1}

Preparation of simulation model is done by several stages, they are:

a. Create a hybrid system scheme block

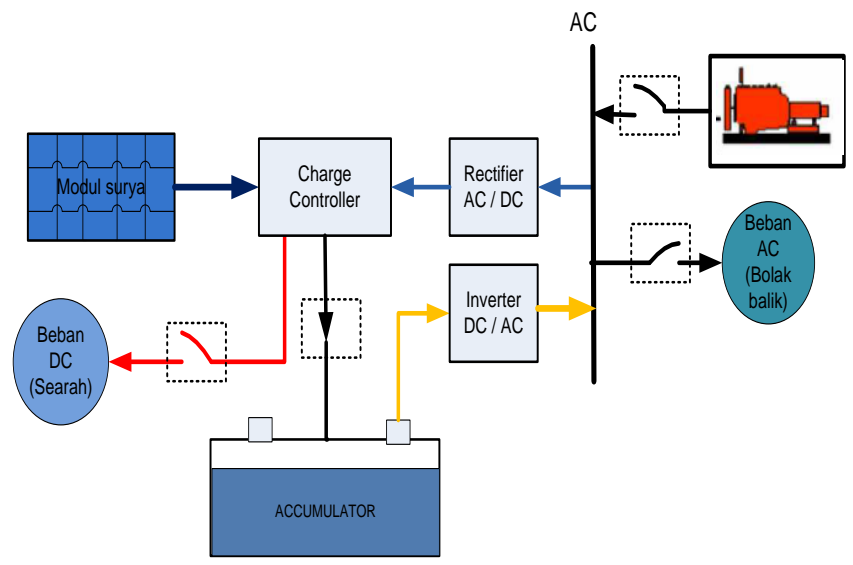

Fig 5: Solar-Diesel / Genset hybrid system scheme 
b. Creating a wiring circuit block from the PLTS hybrid system with the PLTD / Genset As in the drawing circuit block 6 .

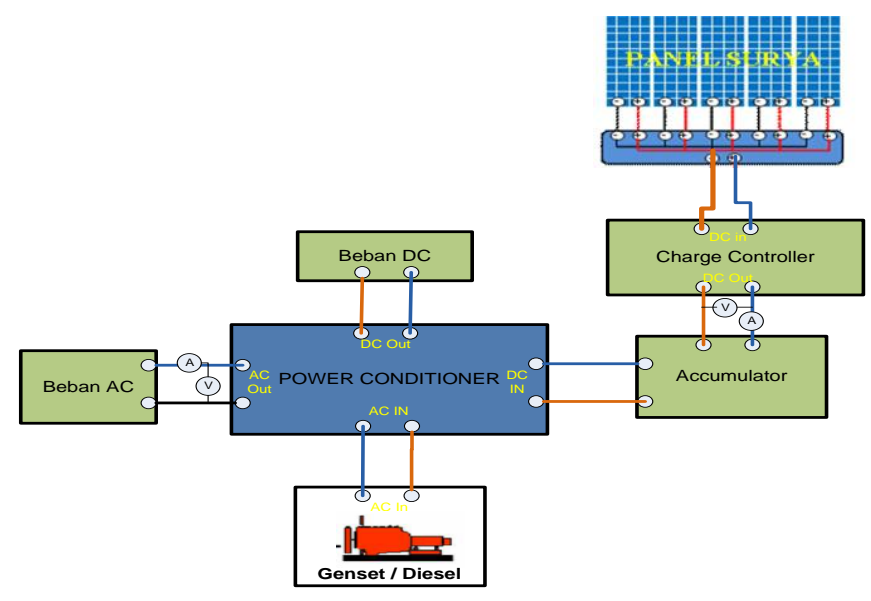

Fig 6: Block Hybrid Solar system wiring circuit with Genset / Diesel

Figure 6 shows that parts of the circuit include parts of PLTS (Solar Panel) and Genset, Power Conditioner circuit (Rectifier / Rectifier and Inverter) and load.

c. Creating a Simulation model in Application of Homer Pro V3.9.1[17]

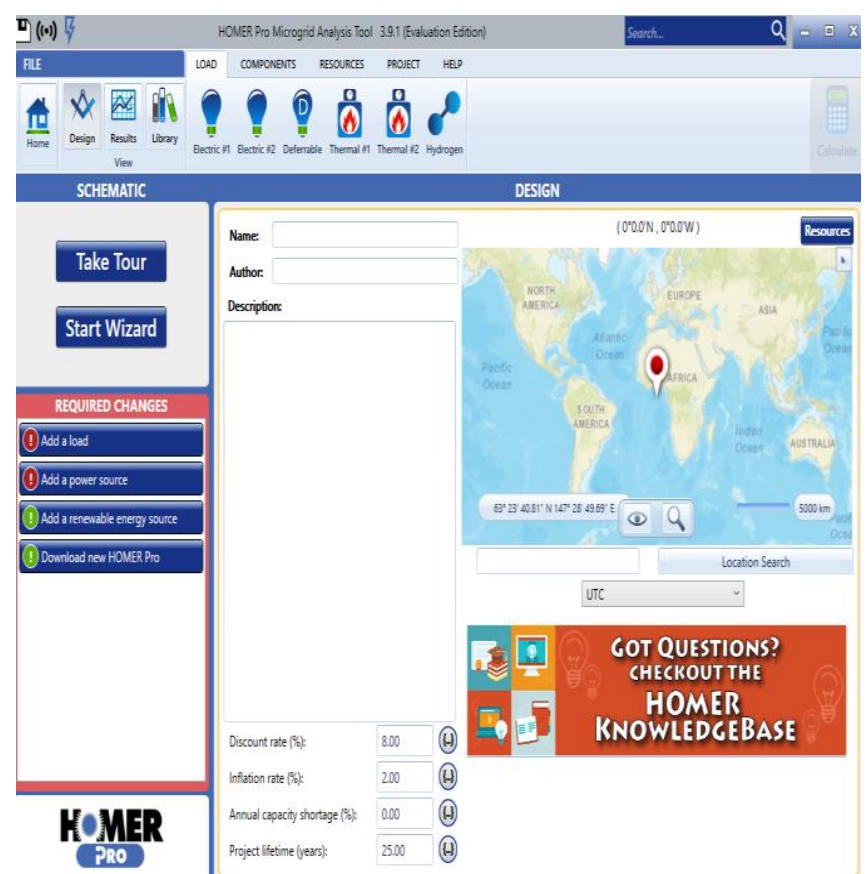

Fig 7: Homer Homepage initial display

d. Create schematic (figure 8) hybrid system based on planned load, panel capacity, Battery capacity, power inverter capacity and Generator

\section{RESULTS AND DISCUSSION}

The planned load data is $500 \mathrm{Wp}$ or $4.05 \mathrm{kWh} / \mathrm{d}$ as in table 3.
The calculation results for the capacity of each component based on the need for a load of $500 \mathrm{Wp}$ is:

1. Energy needed in 1 hour $E=500 \mathrm{Wh}$

2. Battery Capacity

The total time needed by consumers in power equipment such as lamps and other equipment with an average load of $169 \mathrm{~W}$ is 14 hours because 12 hours of sun does not shine while the battery charging effectively in hot weather from $07.00-17.00$, then the total energy needed is : $E=2366 \mathrm{Wh}$

So the Battery capacity in Ampere-Hour (Ah) is:

$$
I_{R M S} x t=219.07 \mathrm{Ah}
$$

Rounded to $219 \mathrm{Ah}$

Table 3: Load Profile

\begin{tabular}{|l|l|l|l|}
\hline Time(hour) & $\begin{array}{c}\text { Load } \\
(\mathrm{kW})\end{array}$ & Time(hour) & $\begin{array}{c}\text { Load } \\
(\mathrm{kW})\end{array}$ \\
\hline 00.00 & 0.060 & 12.00 & 0.250 \\
\hline 01.00 & 0.060 & 13.00 & 0.220 \\
\hline 02.00 & 0.060 & 14.00 & 0.180 \\
\hline 03.00 & 0.060 & 15.00 & 0.160 \\
\hline 04.00 & 0.090 & 16.00 & 0.150 \\
\hline 05.00 & 0.180 & 17.00 & 0.200 \\
\hline 06.00 & 0.270 & 18.00 & 0.240 \\
\hline 07.00 & 0.260 & 19.00 & 0.297 \\
\hline 08.00 & 0.211 & 20.00 & 0.270 \\
\hline 09.00 & 0.140 & 21.00 & 0.190 \\
\hline 10.00 & 0.150 & 22.00 & 0.100 \\
\hline 11.00 & 0.180 & 23.00 & 0.070 \\
\hline & & Total & $\mathbf{4 . 0 5 0}$ \\
\hline
\end{tabular}

Inverter efficiency value of $90 \%$, then the remaining $10 \%$ wasted into heat then redefined the value of battery capacity of $10 \%$ of the Ampere hour (Ah) value that has been obtained then the battery capacity becomes:

$$
I_{R M S} x t=240.98 A h
$$

Battery capacity calculation is not always ideal because the battery should not be used until it runs out so that the DOD (Depth of Discharge) that affects the battery life of the cycle so as to be considered. For Battery with Type VRLA 100 Ah has a maximum voltage rating of 12 Volts with a capacity of $100 \mathrm{Ah}$, then the capacity can be calculated only by $80 \%$ of 100 Ah while $20 \%$ to avoid DOD, so:

$$
I_{R M S} x t=289.18 \mathrm{Ah}
$$

Then the amount of Battery needed is 2.89 pieces rounded into 3 pieces of battery with a capacity of each $100 \mathrm{Ah}$ 
3. Solar Panel

The planned solar panel is a polycrystaline type with a capacity of $50 \mathrm{~W}$ capable of producing 50 Whale Output, then the number of solar panels required is:

$$
n_{p}=16.24 \text { buah }
$$

Rounded into 16 pieces

\section{Charge Controller}

The amount of charge controller required depends on the maximum load allowed on the device. To charge Solar Charge Controller MPPT30 12/24 volt (auto) means that the maximum load that can be served is 30 Ampere, then the amount of charge controller used to charge Battery for 10 Hours is:

$$
n_{c g}=1.04 \text { pieces }
$$

rounded into 1 piece

\section{Power Inverter}

Power inverters are calculated based on the maximum load allowed on the device. Suppose Power Inverter 500 W VMI-P500, has a maximum load of $500 \mathrm{~W}$. Thus for electrical energy required in 1 hour for $500 \mathrm{~W}$ power is $500 \mathrm{Wh}$ then the number of inverters required is:

$$
n_{i}=1 \text { buah }
$$

From the data in table 3 it is shown that the load requirement in one day is $4.05 \mathrm{kWh}$ or $0.169 \mathrm{Wh}$ average.

This condition is then simulated using Homer Pro 3.9.1 as shown in Figure 7 and simulation scheme as shown in Figure 8. The simulation output can be seen in Figure 9.

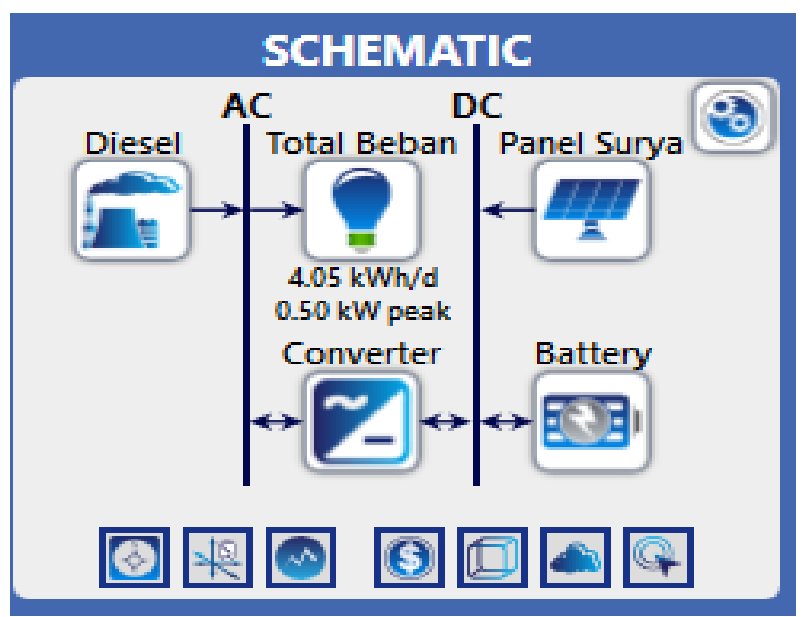

Fig 8: Schematic of Homer Pro V3.91 Application based on load requirement of $500 \mathrm{Wp}$

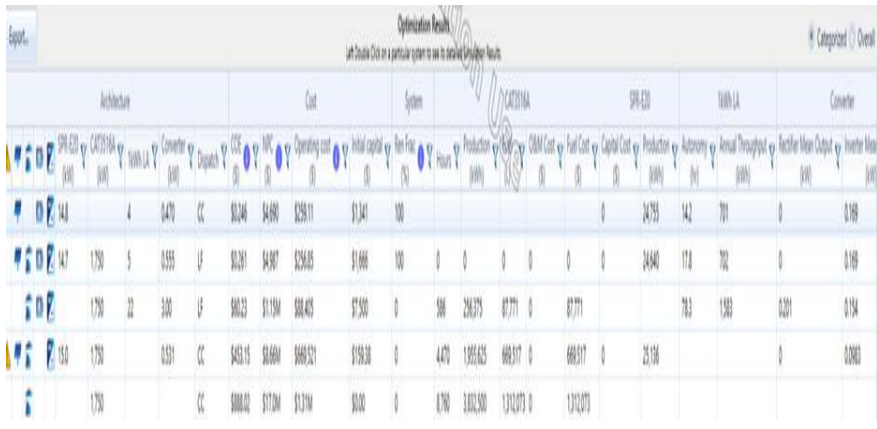

Fig 9: Results Hybrid system simulation using Homer Pro Application V3.9.1

Simulation results obtained can be explained that:

1. Power source from solar panel only, generator only, and combination Genset / Diesel and solar panel, is feasible technically

2. PV panels as the most economical source of electrical energy. This can be seen from the smallest NPC value, which is $\$ 4,690$. Combination of PV Panel with Diesel / Genset for \$ 4,987 and Genset / Diesel only has NPC become biggest $(\$) 1.15 \mathrm{M}$, because operational cost from system with generator is very big.

3. The output capacity of the inverter is $0.169 \mathrm{~kW}$ or 169 W.

\section{CONCLUSION}

Based on the simulation model that has been made can be concluded that:

a. Diesel generator / diesel generator model generated for $500 \mathrm{Wp}$ load requires $0.169 \mathrm{~kW}$ power inventer

b. Simulations with HOMER PRO V3.9.1 indicate that the only source of electricity from solar panels, gensets alone, and the combination of generators and solar panels is technically feasible. Figure 16 shows the simulation and optimization results performed by HOMER PRO V3.9.1. PV panels as the most economical source of electrical energy. This can be seen from the smallest NPC value, which is \$4,690. Combination of PV Panel with Diesel / Genset for \$ 4,987 and Genset / Diesel only has NPC become biggest (\$) $1.15 \mathrm{M}$, because operational cost from system with Genset / Diesel is very big.

\section{ACKNOWLEDGEMENT}

This study is a Research Competitive Grant Number: DIPA 1491/K9/KT.03/2017 dated $26^{\text {th }}$ April 2017, for that we would like to thank DitLitabmas that gives research funding.

\section{REFERENCES}

[1]. Agus Adria dan Tarmizi, 2015. Model Hibrid PVGenset Aplikasi pada Sistem Off-Grid. Seminar Nasional dan Expo Teknik Elektro 2015, hal. 96-101, ISSN: 20889984

[2]. El-wakil, M. M. 1984. Powerplant Technology. Mc Graw-Hill Book Company, Singapore 
[3]. Gray Davis, Juni 2001, a guide to photovoltaic (PV) system design and installation, California, Regional Economic Research, Inc

[4]. Abubakar, Sudrajat, Adjat. 2006. Listrik Tenaga Surya fotovoltaik. BPPT PRESS, Jakarta.

[5]. Liem Ek Bien, Ishak Kasim \& Wahyu Wibowo, Agustus 2008. Perancangan system hybrid Pembangkit Listrik Tenaga Surya dengan Jala-jala Listrik PLN untuk rumah Perkotaan, JETri, Universitas Trisakti, Jakarta.

[6]. Matius Sau, 2013. Desain sistem hibrid pembangkit listrik tenaga surya dengan pembangkit listrik tenaga diesel sebagai alternatif hemat energi, Laporan Penelitian Dosen Pemula.

[7]. Rahadian Muda S, 2009. Pemanfaatan Sel Surya Sebagai Catu Daya Sistem Pendingin Mekanis Pada Kapal Ikan, Teknik Perkapalan, ITS Surabaya.

[8]. Yuliarto B, 2006. Energi Surya: Alternatif Sumber Energi Masa Depan di Indonesia, Berita Iptek. 2006.

[9]. www.solarnavigator.net, Penggunaan sel surya pada kapal supertanker.

[10]. Watson, G. O. 1983. Marine Electrical, Practice $5^{\text {th }}$ Edition. England, Butterworths.

[11]. Wing, Charles. 1993. Boatowner's Wiring Manual. London, Adlard Coles Nautical.

[12]. Djojohadikusuma, 2006. Perencanaan PLTS Institut Teknologi Bandung.

[13]. PT. Smiko. 2010. Brosur Teknik Spesifikasi Modul surya. Laboratorium PT. Smiko. Jakarta [14]. Unggul W. Energi Listrik Baru Terbarukan. Universitas Brawijaya. Malang. 2008

[15]. C, SNI 04-6394-2000. Prosedur penentuan klasifikasi sistem pembangkit listrik fotovoltaik individual - $\quad$ Pedoman umum http://sisni.bsn.go.id/index.php?/sni_main/sni/detail_sni_2/5 997

[16]. Optimum slope angle and orientation of solar collectors for different periods of possible utilization. https://www.researchgate.net/publication/245159537

[17]. Homer, Hybrid Optimization Model for Electric Renewables, HOMER Pro Software V3.9.1., www.homer energy.com. (2016)

\section{BIOGRAPHIES}

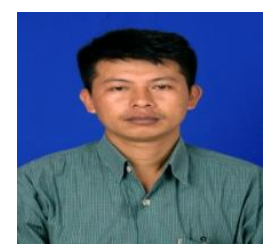

Matius Sau', Was born in Tumbang Datu, July 7, 1975. The author graduated from Postgraduate Electrical Engineering in Power System field at the Bandung Institute of Technology. Has produced several scientific papers / research, among others, research Electrical Fields Biological Impacts Control System Along High Voltage Air Transmission Line of South Sulawesi Systems (Cases: Tello-Pangkep and Tello-Sungguminasa Tansmission System) (2012/as chairman). The author is also as a speaker at national and international seminars.

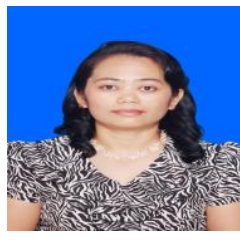

Hestikah Eirene Patoding, Was born in Palopo, April 7, 1971. The author graduated from Postgraduate Electrical Engineering at the University of Hasanuddin, Makassar, Indonesia. Has produced several scientific papers / research, among others, research Optimization Placement of Capacitors Electrical System in Sulselbar As An Alternative Energy Using Genetic Algorithm (2012/as chairman) and Modeling Control of Automatic Voltage Regulator with a Proportional Integral Derivative to Changes Reactive Loads System in the in Gas Power Plant (2014/as chairman). The author is also as a speaker at national and international seminars. 